\title{
Teologia naturalna Stokesa
}

George Gabriel Stokes (13 VIII 1819-1 II 1903) był najmłodszym spośród ośmiorga rodzeństwa (dzieciństwo przeżyło czterech chłopców i dwie dziewczynki). ${ }^{1}$ Dorastał w bardzo religijnej rodzinie. Jego ojciec, Gabriel Stokes, był pastorem parafii Skreen, w irlandzkim hrabstwie Sligo. Matka, Elizabeth Haughton, była córką pastora. Starsi bracia poszli w ślady ojca. George odebrał wykształcenie domowe, a w 1832 roku opuścił rodzinną wieś i wyjechał do Dublina, gdzie poszedł do szkoły. Przez ten czas mieszkał ze swoim wujem. Wówczas upodobał sobie matematykę, a szczególnie rozwiązywanie zadań z geometrii. Po trzech latach pobytu w Dublinie życie Stokesa zmieniło się gwałtownie, zmarł mu ojciec. Wkrótce po tym, w wieku 16 lat, Stokes przeniósł się do Anglii i podjął naukę w Bristol College. Spędził tam dwa lata, czyniąc olbrzymie postępy i przygotowując się do podjęcia studiów. W 1837 roku podjął naukę w Cambridge. Na studiach uczył go między innymi William Hopkins, na którym bardzo duże wrażenie wywarły ówczesne zainteresowania Stokesa. W 1841

* Studentka filozofii i astronomii na Uniwersytecie Zielonogórskim.

${ }^{* *}$ Recenzent: Tomasz BuLIK, Obserwatorium Astronomiczne Uniwersytetu Warszawskiego. Przypisy redakcyjne i rysunki: Robert PIotrowski, Instytut Filozofii Uniwersytetu Zielonogórskiego.

${ }^{1}$ Informacje biograficzne na podstawie Memoir and Scientific Correspondence of the Late Sir George Gabriel Stokes, vol. I-II, ed. Joseph Larmor, The University Press, Cambridge 1907 oraz J.J. O'CONNOR et al., „George Gabriel Stokes”, http://www-history.mcs.st-an drews.ac.uk/Biographies/Stokes.html. Dzieła zebrane Stokesa: Mathematical and Physical Papers, vol. I-V, The University Press, Cambridge 1880-1905. 
roku Stokes skończył z wyróżnieniem studia i dość szybko otrzymał stypendium. Początkowo, za namową Hopkinsa i pod wpływem George'a Greena, zajmował się hydrodynamiką. Wówczas powstało jego pierwsze dzieło On the Steady Motion of Incompressible Fluids (1842). Kolejne również dotyczyły mechaniki płynów, m.in. On the Theories of the Internal Friction of Fluids in Motion (1845) i Report of Recent Researches in Hydrodynamics (1846). Oprócz tego zajmował się falową teorią światła, badając aberrację i dyfrakcję. W 1849 roku Stokes objął katedrę matematyki w Cambridge, a dwa lata później został członkiem Royal Society. W 1857 roku ożenił się z Mary Robinson, przez co na pięć lat stracił stypendium naukowe w Pembroke College, które odzyskał dopiero po zmianie przepisów, rezerwujących stypendia dla kawalerów. W latach 1854-1885 Stokes pełnił funkcję sekretarza Royal Society, a w latach 1885-1890 - prezesa. W latach 1886-1903 był prezesem Victoria Institute, ${ }^{2}$ zrzeszającego przede wszystkim kreacjonistów, sceptyków wobec ewolucjonizmu lub tych, którzy jak Stokes starali się godzić ewolucjonizm z kreacjonizmem. W 1889 roku w dowód uznania jego zasług dla nauki przyznano mu tytuł szlachecki. Był raczej małomówny. Jego córka tak go opisuje:

W jego osobowości było coś bardzo pociągającego, w tym połączeniu spokoju i aktywności jego ciała i umysłu, w jego sile i delikatności, w dumie i pokorze charakteru, mądrości i całkowitej skromności, wytrwałości w wierze naturze i prostej uprzejmości. [...] Był raczej niski, mocnej i silnej budowy, osoba jego była raczej silna niż pełna wdzięku, jego głowa bardzo duża, lecz jednocześnie bardzo kształtna i proporcjonalna [...] oczy raczej małe, pełne życia, o szaroniebieskiej barwie i blasku, jego czysta, lekko rumiana cera ukazywała obraz człowieka pełnego zdrowia. ${ }^{3}$

\footnotetext{
${ }^{2}$ (Przyp. red.) Victoria Institute or Philosophical Society of Great Britain powstał w roku 1865 w reakcji na postępy ewolucjonizmu po ukazaniu się O powstawaniu gatunków Darwina. Największą popularnością cieszył się w ostatnich latach XIX wieku. Mimo wielokrotnych zaproszeń członkostwo Instytutu odrzucił James Clerk Maxwell. Victoria Institute działa do dzisiaj pod roboczą nazwą Faith and Thought.

${ }^{3}$ Stokes, Memoir and Scientific Correspondence..., vol. I, s. 12.
} 


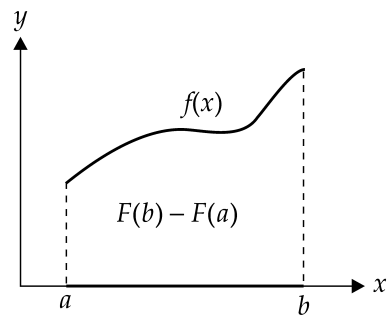

Jeżeli $F$ jest funkcją pierwotną dla $f$ na przedziale $[a, b]$, to: $\int^{b} f(x)=F(b)-F(a)$

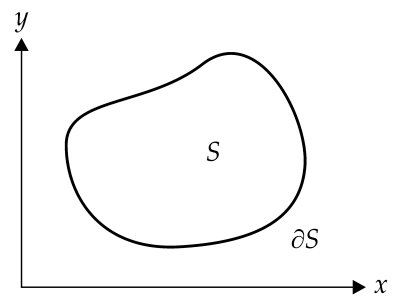

Dla dwóch funkcji $L$ i $M$ ciągłych wraz z pochodnymi na normalnym obszarze płaskim $S$ i jego brzegu $\partial S$ :

$$
\oint_{\partial S}(L d x+M d y)=\iint_{S}\left(\frac{\partial M}{\partial x}-\frac{\partial L}{\partial y}\right) d S
$$

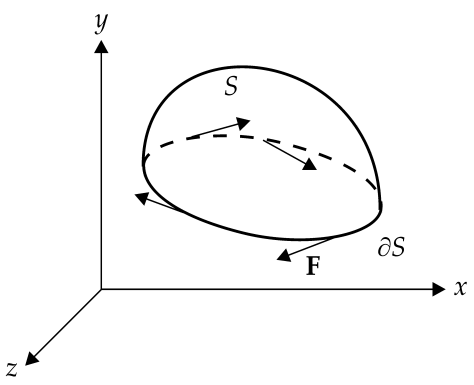

$\iint_{\partial S} \mathbf{F} d r=\int_{S} \nabla \times \mathbf{F} d S$

Rys. 1. Jedno-, dwu- i trójwymiarowy przypadek twierdzenia Stokesa. Przypadek jednowymiarowy to podstawowe twierdzenie analizy, zaś dwuwymiarowy to twierdzenie Greena (rys. i przyp. red.).

W nauce Stokes znany jest głównie $\mathrm{z}$ twierdzenia Stokesa oraz równania Naviera ${ }^{4}$-Stokesa, opisującego ruch płynu lepkiego. W wersji trójwymiarowej twierdzenie Stokesa głosi, że całka krzywoliniowa, skierowana z pola wektorowego $\mathbf{F}$ po brzegu $\partial S$ płata powierzchnio-

\footnotetext{
${ }^{4}$ Claude Louis Navier (1785-1836) - francuski inżynier i fizyk.
} 
wego $S$, jest równa całce, zorientowanej z rotacji pola wektorowego $\mathbf{F}$ po płacie powierzchniowym $S$. Swobodniej i odwołując się do intuicji geometrycznej: obieg pola wektorowego po krawędzi płata powierzchni (,strzałek" stycznych do tej krawędzi) równa się sumie przepływu pewnej funkcji (tzw. rotacji) tych strzałek przez całą ową powierzchnię (por. rys. 1).

Twierdzenie to szeroko stosowane jest m.in. w matematycznej i fizycznej teorii pola (w tym w równaniach Maxwella) i hydrodynamice. Nie pojawiło się zresztą w próżni, a jego historia jest udziałem wielu matematyków ${ }^{5}$ - od Gaussa ${ }^{6}$ (jeszcze w 1813 roku) przez Ostrogradskiego, ${ }^{7}$ Poissona, ${ }^{8}$ Sarrusa, ${ }^{9}$ Greena ${ }^{10}$ (jako pierwszy podał przypadek dwuwymiarowy), Cauchy'ego, ${ }^{11}$ Williama Thomsona, ${ }^{12}$ aż do Riemanna ${ }^{13}$ i Hankela ${ }^{14}$ (pierwszy opublikowany ogólny dowód, 1860). Sam Stokes znalazł się w tym towarzystwie cokolwiek przypadkowo, ogłosił sformułowanie, zakomunikowane mu przez Kelvina w 1850 roku. $^{15}$ Dodajmy, że każdy, kto wtedy miał do czynienia z tym twierdzeniem, szukał jego zastosowania w innej dziedzinie fizyki.

\footnotetext{
${ }^{5}$ Por. Victor Katz, „The History of Stokes' Theorem”, Mathematics Magazine, May 1979, vol. 52, no. 3, s. 146-156.

${ }^{6}$ Carl Friedrich Gauß (1777-1855) - niemiecki matematyk, fizyk, astronom i geodeta.

${ }^{7}$ Michał Wasiliewicz Ostrogradski (1801-1862) - matematyk rosyjski.

${ }^{8}$ Simeon Denis Poisson (1781-1840) - fizyk i matematyk francuski.

${ }^{9}$ Pierre Frederick Sarrus (1798-1861) - matematyk francuski.

${ }^{10}$ George Green (1793-1841) - matematyk angielski.

${ }^{11}$ Augustin-Louis Cauchy (1798-1857) - matematyk francuski.

${ }^{12}$ William Thomson, 1. baron Kelvin (1824-1907) - fizyk, matematyk i inżynier brytyjski pochodzenia irlandzkiego.

${ }^{13}$ Bernhard Riemann (1826-1866) - matematyk niemiecki.

${ }^{14}$ Hermann Hankel (1839-1873) - matematyk niemiecki.

${ }^{15}$ (Przyp. red.) Następnie Stokes w roku 1854 zadał na egzaminie konkursowym im. Roberta Smitha dowód studentom, co zostało potem skojarzone przez Maxwella, por. STOKES, Mathematical and Physical Papers..., vol. V, s. 320; Peter M. HARMAn, The Natural Philosophy of James Clerk Maxwell, Cambridge University Press, Cambridge 1998, s. 152.
} 
Gauss badał magnetyzm, Ostrogradski - termodynamikę, Green elektromagnetyzm, Poisson - sprężystość, a Sarrus - pływanie ciał. Dopiero sformułowanie Kelvina-Stokesa ujawniło uogólnienie tych wszystkich przypadków, stosowalne w całej fizyce. Twierdzenie Stokesa we współczesnym sformułowaniu jest jednym z fundamentalnych rezultatów analizy matematycznej. ${ }^{16}$

Co do równania Naviera-Stokesa, opisuje ono ruch cieczy lepkich i w przypadku stałych współczynników lepkości ma postać:

$$
\frac{d \mathbf{v}}{d t}=\mathbf{F}-\frac{1}{\rho} \nabla p+v \Delta \mathbf{v}+\left(\frac{\zeta}{\rho}+\frac{v}{3}\right) \nabla(\nabla \cdot \mathbf{v}),
$$

gdzie: $\mathbf{v}$ - prędkość cieczy, $\mathbf{F}$ - natężenie pola sił masowych, $p$ - ciśnienie, $\rho$ - gęstość, $v$ - współczynnik lepkości kinematycznej, $\zeta-$ współczynnik lepkości objętościowej.

Podobnie jak twierdzenie Stokesa, nie miało ono jednego odkrywcy. Jest wynikiem burzliwego rozwoju hydrodynamiki w XIX wie$\mathrm{ku} .{ }^{17} \mathrm{~W}$ różnych sformułowaniach i z różnymi uzasadnieniami ogłaszali je od 1822 do 1845 kolejno Navier, Cauchy, Poisson, Saint-Venant ${ }^{18}$ i wreszcie Stokes. ${ }^{19}$ Ten ostatni zainteresował się serią do-

\footnotetext{
${ }^{16}$ (Przyp. red.) Tzn. w kolejnym uogólnieniu - na więcej niż trzy wymiary. W oryginalnym sformułowaniu występują mianowicie twory co najwyżej trójwymiarowe: płaty powierzchni i co najwyżej dwuwymiarowe: krawędzie tych płatów. Ponadto całkowanymi wielkościami są wektor trójwymiarowy i jego rotacja (pewna funkcja pochodnych tegoż wektora). Natomiast uogólniona wersja twierdzenia Stokesa utożsamia całkę pewnego tworu różniczkowego (tzw. formy różniczkowej) po krawędzi uogólnionej bryły (tzw. rozmaitości) z uogólnioną pochodną takiej formy po wnętrzu owej bryły.

${ }^{17}$ Oliver DarRigol, Worlds of Flow: A History of Hydrodynamics from the Bernoullis to Prandtl, Oxford University Press, Oksford 2005, rozdz. 3. „Viscosity”.

${ }^{18}$ Adhémar Jean de Saint-Venant (1797-1886) - inżynier francuski.
} 
świadczeń Sabine'a ${ }^{20}$ nad ruchem wahadeł sekundowych kształtu walcowego i kulistego, w powietrzu i wodorze. Stokes doszedł do wniosku, że istnieją trzy możliwe przyczyny różnic w oporze ośrodka: tarcie, nieciągłości przepływu lub niestabilności, prowadzące do turbulencji. Ostatecznie udało mu się włączyć tarcie wewnętrzne (tj. lepkość) do podstawowych równań dynamiki płynów. W 1850 roku wyjaśnił wyniki pomiarów Sabine’a i wprowadził pojęcie współczynnika lepkości. ${ }^{21} \mathrm{Z}$ kolei prawo Stokesa określa siłę oporu, wynikającego z lepkości dla małych, w przybliżeniu kulistych, obiektów opływanych w sposób laminarny; stanowi ono szczególne rozwiązanie równania Naviera-Stokesa. Co do innych dziedzin fizyki, w fotometrii znana jest reguła Stokesa, zgodnie z którą długość fali fotoluminescencyjnej przekracza długość fali światła, wzbudzającego fotoluminescencję.

W Teologii naturalnej Stokes przedstawił się jako zwolennik naturalizmu. Na dzieło to składają się dwa cykle wykładów. ${ }^{22}$ Głównym celem dzieła jest wyjaśnienie egzystencji Boga i ustalenie idealnego systemu norm moralnych w oparciu o ludzki intelekt, tzn. analogicznie do metody przyrodoznawczej. Stokes wychodzi z założenia, że w teologii naturalnej, tak samo jak w naukach przyrodniczych, rozwój teorii możliwy jest dwojako. Po pierwsze, poprzez wydedukowanie pewnych twierdzeń na podstawie tego, co już wiemy lub obserwuje-

\footnotetext{
${ }^{19}$ STOKES, „On the Theories of the Internal Friction of Fluids in Motion, and of the Equilibrium and Motion of Elastic Solids", w: Mathematical and Physical Papers..., vol. I, s. 75-129; por. Darrigol, Worlds of Flow..., s. 136-140.

${ }^{20}$ Sir Edward Sabine (1788-1883) - irlandzki geofizyk, astronom i podróżnik.

${ }^{21}$ STOKes, „On the Effect of the Internal Friction of Fluids on the Motion of Pendulums”, w: Mathematical and Physical Papers..., vol. III, s. 1-141.

${ }^{22}$ Stokes, Natural Theology. The Gifford Lectures, Adam and Charles Black, London 1891-1893.
} 
my. Po drugie, poprzez przyjmowanie hipotez, a następnie szukanie ich potwierdzenia w obserwacjach. Pod tym względem, metody teologii naturalnej nie różnią się od metod nauk ścisłych. Do podstawowych problemów, jakimi zajmuje się teologia naturalna, Stokes zaliczał wyjaśnienie egzystencji Boga. Dlatego jedno z pierwszych i najważniejszych pytań, jakie postawił w swoim dziele, brzmi:

Skąd się bierze wiara w Boga? Czy (1) z intuicji, czy (2) pochodzi z przekazu jakiegoś pierwotnego objawienia, czy (3) została wywnioskowana na podstawie obserwacji przyrody i samoobserwacji? ${ }^{23}$

Stokes skłaniał się ku trzeciej możliwości, argumentując na rzecz racjonalnego pochodzenia wiary w Boga. Opisał rozwój dziecka, zwracając uwagę na fakt, że jedną z pierwszych idei, jakie nabywa dziecko, jest idea przyczynowości. W świecie dziecka idea Boga pojawia się wtedy, kiedy stara się ono znaleźć sprawcę tych wszystkich rzeczy, których pojawienie się w żaden inny sposób nie potrafi wyjaśnić. Bóg jest wówczas w wyobrażeniach dziecka niewidzialnym sprawcą, który czyni rzeczy podług swej woli. Wola z kolei implikuje osobowy charakter Boga. W ten sposób, zdaniem Stokesa, nabywamy wyobrażenia o Bogu. Zupełnie inaczej ma się rzecz z prawami przyrody, które wcale nie pociągają za sobą istnienia woli, a często nawet również idei przyczynowości. Jako przykład dał zmiany pór roku, wynikające $\mathrm{z}$ nałożenia się dwóch praw: ruchu obiegowego Ziemi oraz ruchu wokół własnej osi. To drugie jest znowu efektem złożenia dwóch kolejnych praw: prawa ruchu i prawa grawitacji. Skąd zatem w nauce wzięła się idea przyczynowości? Dlaczego, mówiąc o Pierwszej Przyczynie, przypisujemy jej istnienie woli, tym samym ją personifikując? Zdaniem Stokesa te idee do nauki wniósł ludzki umysł, który poszukuje przede wszystkim uniwersalnej zasady wyjaśniającej wszystko.

\footnotetext{
${ }^{23}$ SтокеS, Natural Theology..., 1891, s. 3.
} 
Stokes przedstawił przykład upraszczania wyjaśnień naukowych. Już w starożytności zauważono, że niektóre gwiazdy poruszają się nietypowo. Dlatego nazwano je planetami, czyli błądzącymi. Astronomie zaczęli tworzyć hipotezy, które wyjaśniałyby ich ruchy, lecz poprawne wyjaśnienie pojawiło się dopiero dzięki prawom Keplera. Te ostatnie nie wyjaśniały zresztą przyczyn ruchu planet, pozwalając jedynie na opis obserwacji i prawidłowe przewidywanie przyszłych ruchów. Tymczasem naukowcy zawsze szukają przyczyn występujących zjawisk. Newton pokazał, że te trzy prawa są konsekwencją prawa ogólniejszego, jakim jest prawo grawitacji. Stokes słusznie przypuszczał, że również i to prawo zostanie objęte przez jakieś ogólniejsze. ${ }^{24}$ Dzieje się tak dlatego, ponieważ ludzie mają naturalną skłonność do tworzenia generalizacji i szukania ogólnych praw, ${ }^{25}$ a z drugiej strony są $\mathrm{z}$ reguły deterministami, uznając że wszelkie zdarzenia muszą mieć swoje przyczyny.

W ten sposób powstaje, między innymi, idea Pierwszej Przyczyny, której nadaje się niekiedy atrybut woli, gdyż ludzie skłonni są wierzyć, iż życie nie powstało przypadkowo, lecz skutkiem czyjegoś zaplanowanego działania. W ten sposób dochodzimy do idei projektu, zgodnie z którą świat został zaprojektowany i stworzony w jednorazowym akcie.

Stokes jednak zdawał sobie sprawę z pewnego problemu, na jaki natrafia kreacjonizm. W tym celu przeprowadził następujący eksperyment myślowy. ${ }^{26}$ Wyobraźmy sobie osobę, która pochodzi z cywilizowanego kraju, w którym w ogóle nie mierzy się czasu. Osoba ta odwiedza kraj, w którym spostrzega zegar. Dla tej osoby ruch wskazówek początkowo nie będzie miał praktycznie żadnego znaczenia. $\mathrm{Z}$ czasem jednak zacznie ona zauważać pewne zależności np. między

\footnotetext{
${ }^{24}$ STOKES, Natural Theology..., 1891, s. 12-14.

${ }^{25}$ Tendencja ta jest również bardzo silna we współczesnej fizyce, w której poszukuje się tzw. „ogólnej teorii wszystkiego”, która obejmowałaby dzisiejsze teorie mechaniki kwantowej i ogólną względności.

${ }^{26}$ STOKES, Natural Theology..., 1891, s. 15-17.
} 
ruchem wskazówek zegara a wschodem i zachodem słońca. W końcu odkryje, że wskazówki zegara odmierzają upływ czasu. Osoba ta musi dojść do wniosku, że obserwowany przez nią zegar ktoś zaprojektował i stworzył. I to jest właśnie przyczyną ruchu wskazówek zegara. Ale jeśli otworzyłaby zegar, jej oczom ukazałby się złożony układ mechanicznych części. Gdyby zaczęła go badać, odkryłaby pewne zależności, aż ostatecznie dowiedziałaby się, że zegar jest tak zbudowany, że jego wahadło jest idealnie wyważone i raz wprawione w ruch, pod wpływem działania grawitacji, wykonuje regularne wahnięcia. Co $\mathrm{w}$ takim razie stało się z pierwotną ideą zaprojektowania i stworzenia zegara w całości? Przecież odkryto inną, pierwotniejszą przyczynę ruchu jego wskazówek. ${ }^{27}$ Podobnie dzieje się w nauce, gdzie stale odkrywamy bardziej ,pierwotne” wyjaśnienia pewnych zjawisk.

Stokes jednak konsekwentnie bronił kreacjonizmu, przedstawiając swoim zdaniem jeden z najsilniejszych argumentów na rzecz idei projektu. Jest nim struktura naszego układu słonecznego oraz budowa naszej planety, które umożliwiły pojawienie się życia na Ziemi.

Układ Słoneczny ma w centrum olbrzymie Słońce o ogromnej temperaturze. Samo w sobie, o ile możemy sądzić, całkowicie niezdatne do zamieszkania przez istoty żywe, Słońce nie tylko utrzymuje planety na swoich orbitach, ale również zawiera tak duży zapas energii promienistej, że musiałyby minąć wieki wieków, żeby się wyczerpał. Energia promienista jest całkowicie niezbędna do tego, żeby na Ziemi mogło istnieć życie w takiej postaci, w jakiej je znamy. [...] mamy zatem układ w godzien podziwu sposób przystosowany do podtrzymania życia na Ziemi, oraz, co bardzo prawdopodobne, też na innych planetach. Możemy słusznie przypuszczać, że ta struktura została stworzona w tym właśnie celu. ${ }^{28}$

\footnotetext{
${ }^{27}$ Stokes czyni tu aluzję do argumentu Paleya na rzecz idei projektu, który odwołuje się do nieprawdopodobieństwa przypadkowego powstania zegarka znalezionego na wrzosowisku.

${ }^{28}$ Stokes, Natural Theology..., 1891, s. 34-35.
} 
Broniąc kreacjonizmu, Stokes zauważał, że stan początkowy (initial state) wymyka się naszemu pojęciu ${ }^{29}$ i nigdy nie stwierdzimy, co właściwie jest, a co nie jest, możliwe w przyrodzie. Zdaniem Stokesa ewolucjonizm wcale nie niszczy kreacjonizmu, lecz jedynie wymusza pewne jego modyfikacje. Gdy traktujemy „stan początkowy” jako punkt wyjścia, nawet przy założeniu słuszności ewolucjonizmu, pozostaje w nim miejsce na Istnienie zdolne do zaprojektowania i stworzenia świata. Stokes stwierdza wręcz:

Słyszałem od poważnej osoby, że sam Darwin uważał, że argument o zaprojektowaniu świata jest raczej wspierany, a nie niszczony, przez zaakceptowanie jego teorii. ${ }^{30}$

Możemy zaliczyć poglądy Stokesa do kreacjonizmu ewolucjonistycznego, ponieważ akceptuje on osiągnięcia Darwina, jednocześnie nie rezygnując $\mathrm{z}$ idei projektu.

Innym zagadnieniem, któremu Stokes poświęcił sporo miejsca, jest wyjaśnienie, w jaki sposób można wyjaśnić istnienie nieśmiertelnej duszy. W tym miejscu jednak musiał on na chwilę opuścić grunt teologii naturalnej, co czynił ze sporą niechęcią, ale jednocześnie zwrócił uwagę, że pewnego rodzaju spekulatywne rozwiązania mogą posiadać dla nauki dużą wartość. Stokes był zdania, że nawet nauki ścisłe nie są wolne od spekulacji. Jako przykład podał przyjęcie przez fizyków hipotezy istnienia eteru, czyli medium, dzięki któremu mogłyby rozchodzić się fale świetlne. Przyjęcie takiego hipotetycznego, nieobserwowalnego bytu przyczyniło się do rozwoju fizyki. Dlatego Stokes postuluje również w trakcie rozważań o genezie umysłu istnienie „ego”.

\footnotetext{
${ }^{29}$ (Przyp. red.) „Przez «stan początkowy» dosłownie rozumiemy tu pewien dający się pomyśleć stan wcześniejszy, przed który nie sięgają nasze spekulacje” (Sтокеs, Natural Theology..., 1891, s. 36).

${ }^{30}$ Stokes, Natural Theology..., 1891, s. 43.
} 
[...] ego jest czymś leżącym głębiej w naszej naturze, niż samo myślenie czymś, co nie ulega zniszczeniu skutkiem zniszczenia ciała, o tyle, o ile nie składa się z materii ważkiej - coś, o czym można przypuścić, że bez jakiegokolwiek zerwania ciągłości zachowuje osobową tożsamość między zmarlym a tym samym człowiekiem w jakimś innym stadium istnienia. ${ }^{31}$

Stokes wyraźnie odrzucał zarówno teorię materialistyczną, jak i teorię, którą nazwał psychiczną ( sychic), a która całkowicie neguje rolę materialnej części organizmu w procesie myślenia. Zwracał uwagę na trudności obu teorii. Pierwsza z nich nie potrafi wyjaśnić, w jaki sposób możliwe byłyby wspomnienia, skoro materia mózgu ulega nieustannej wymianie. Druga z kolei ignoruje fakty, jakich dostarcza nam fizjologia o powiązaniu myślenia ze stanami mózgu. Stokes posłużył się tu analogią z fonografem:

W tym przyrządzie za pośrednictwem odbiornika dokonywane są na woskowym cylindrze niewielkie wcięcia pochodzące od dźwięków wydanych w sąsiedztwie. W ten sposób instrument zapisuje dźwięki ze swojego sąsiedztwa. Te wcięcia są zachowywane i dzięki nim zarejestrowane dźwięki lub ich część mogą być potem dowolnie odtwarzane czy powtarzane i to wielokrotnie za pomocą odpowiedniego urządzenia emitującego. Chciałbym porównać ten woskowy cylinder do bycia osobowego, do ego; zapis na walcu do wrażeń zewnętrznych; pozostawanie śladów na cylindrze do zachowywania w umyśle czegoś, co przeszło przez myśl lecz o czym się w danej chwili nie myśli; odtwarzanie uprzednio zarejestrowanego dźwięku do wspomnienia czegoś, co się wydarzyło. ${ }^{32}$

$\mathrm{Na}$ walcu można zapisać całą długą przemowę. Tam mieści się cały zapis, poza słyszalnością, poza umysłem, może w ogóle zapomniany. Ale jest, w każdej chwili można go wyciągnąć, $w$ razie potrzeby przekonać mówcę, że powiedział był, czego nie powinien. Pod jednym względem ta analogia nie obrazuje tego, co bym chciał powiedzieć. Woskowy cylinder pozwala odtworzenie tego, co zostało zarejestrowane po kolei, tak, jak zostało to nagrane. Analogia zawodzi więc przy wyjaśnianiu domniemanej aktywności, oraz szybkości przeskakiwania my-

\footnotetext{
${ }^{31}$ Stokes, Natural Theology..., 1891, s. 95.

${ }^{32}$ Stokes, Natural Theology..., 1891, s. 96.
} 
śli od przedmiotu do przedmiotu, którą przypisujemy pamięci bytu, obdarzonego bardziej subtelnym ciałem. ${ }^{33}$

Stokes, analizując istotę ego, zwrócił szczególną uwagę na wyjaśnienie, w jaki sposób funkcjonuje pamięć. Zgodnie z chrześcijańską obietnicą będzie życie po śmierci. Zdaniem Stokesa ego jest bytem, który potrafi kierować zdolną do myślenia substancją. Ego jest jednocześnie odpowiedzialne za przywoływanie wspomnień. Jeżeli jednak znajduje się ono poza ciałem, oznacza to, że nie ulega ono zniszczeniu podczas śmierci. Co za tym idzie, gwarantuje ono, że po śmierci może zostać połączone z czymś nowym, w czym znowu będzie kierowało myślami i będzie odpowiedzialne za przywoływanie wspomnień i zachowywanie własnej tożsamości.

Rozmyślania te posiadały również pewien wymiar moralny. Stokes zwracał uwagę, że ludzkie nawyki kształtowane są stopniowo, chociaż czasem jakaś drastyczna zmiana w życiu potrafi całkowicie odmienić człowieka. Stokes posłużył się w tym miejscu analogią astronomiczną:

Pomijając wzajemne perturbacje, planety poruszają się zgodnie z prostymi prawami Keplera. Aczkolwiek planety zakłócają wzajemnie swoje ruchy, to w każdym niewielkim czasie te zakłócenia są niewielkie. Powstają w ten sposób tzw. cykliczne nieregularności. Jednak powtarzanie tych zakłóceń stopniowo zmienia orbitę planety. Zmiana ta, w przeciwieństwie do poprzednich, nie jest mała, choć następuje bardzo powoli. Takie zmiany nazywane są zmianami wiekowymi. Wówczas Clifford ${ }^{34}$ porównał czyny do perturbacji, zaś stopniową zmianę charakteru wynikającą z powtarzania działań - do wiekowych zmian orbit planet. ${ }^{35}$

\footnotetext{
${ }^{33}$ STокеs, Natural Theology..., 1891, s. 103-104.

${ }^{34}$ (Przyp. red.) William Kingdon Clifford (1845-1879) - matematyk i filozof angielski. Analogia między zmianami moralnymi a ruchami planet przeprowadzona została przez Clifforda w eseju „On Some of the Conditions of Mental Developments”, w: Lectures and Essays, vol. I, Macmillan \& Co., London 1901, s. 79-119.

${ }^{35}$ Stokes, Natural Theology..., 1891, s. 105.
} 
Zdaniem Stokesa w stanie po śmierci człowiek miałby zostać wynagrodzony za wszystkie swoje dobre uczynki i ukarany za to, co uczynił złego. Jego rozważania, dotyczące istnienia nieśmiertelnej duszy, którą nazywa ego, podsumowują następujące słowa:

Jak wiemy, obserwacje fizjologiczne pokazują, że mózg jest ściśle związany ze znanym nam procesem myślenia i żebyśmy mogli myśleć, musi być aktywny. Jednocześnie istnieją poważne trudności, związane z założeniem, że myślenie nie jest niczym więcej, jak fizyczną aktywnością organizmu. Najbardziej prawdopodobnym rozwiązaniem jest przyjęcie, że istnieje coś nieznanego, co nie składa się z ważkiej materii, lecz co kieruje ważką materią, znajdującą się w ciele, a myślenie, jakie znamy, jest wynikiem interakcji między nimi. To nieznane coś jest tym, od czego zależy ludzka tożsamość, w związku z czym możemy je zwać ego. Pamięć zależałaby od czegoś, co rejestruje ego, a zapis może zostać przywołany dzięki interakcji z materialnym organizmem. Ego nie ulega zniszczeniu podczas snu lub omdlenia, choć na ten czas myśli pozostają zawieszone. Ponieważ nie składa się z ważkiej substancji, to nie możemy twierdzić, iż ulega zniszczeniu po śmierci, która niszczy organizm materialny. Możemy uważać, że myślenie prawdopodobnie się wtedy zatrzymuje. Lecz jeśli ego niejako przejmie dowództwo nowego organizmu, myślenie może zostać wznowione, a świadomość własnej tożsamości odzyskana, tak jak po okresie snu lub omdlenia. A jeśli ten nowy organizm, nieważne czy materialny, czy też nie, będzie subtelniejszy i lepiej przystosowany do aktywności umysłowej, polegającej na interakcji z ego, niż obecne ciało, które musi zaspokajać naturalne potrzeby, to możemy przypuścić, iż aktywność pamięci i w ogóle moc umysłowa okażą się wtedy znacznie większe. Można wyobrazić sobie, że każdy czyn w naszym życiu, a przynajmniej czyn, który w najmniejszym stopniu kształtował nasz charakter, objawiłby się całkowicie w naszej pamięci, że każdy dobry i zły uczynek mógłby zostać przypominany z bólem lub zadowoleniem. ${ }^{36}$

Jak widać, Stokes jasno wyłożył swoje poglądy, posługując się przy tym obrazowymi przykładami nie tylko z fizyki czy astronomii, lecz i filozofii. Jednakże większość jego argumentów nie jest oryginalna. Wielu filozofów przed nim powoływało się na idealną harmonię świata, która umożliwiła powstanie życia na ziemi, jako na dowód ist-

\footnotetext{
${ }^{36}$ Stokes, Natural Theology..., 1891, s. 105-106.
} 
nienia Stwórcy-projektanta. Podobnych argumentów używał już chociażby św. Tomasz z Akwinu, konstruując swoje „drogi”. To samo wyrażała Paleyowska metafora Zegarmistrza. Lecz jednocześnie są to argumenty, które wcale nie straciły na aktualności. Najbardziej interesującą cechą teologii naturalnej Stokesa pozostaje, moim zdaniem, pogodzenie ze sobą kreacjonizmu z ewolucjonizmem. Interesujące wydają się również rozważania Stokesa z pogranicza naturalnej teologii i czystej spekulacji (do których zaliczył on między innymi rozważania dotyczące ego). Mimo iż autor stale podkreśla, że nie posiadają one naukowej wartości, to jednak nie są przecież bezsensowne. Stokes uświadamia nam w ten sposób, że również postęp nauki możliwy był dzięki mniej lub bardziej uprawnionym spekulacjom. Dlatego warto również współcześnie zapoznać się z twórczością tego myśliciela, która do dnia dzisiejszego nie została, niestety, przełożona na język polski.

Karolina Rożko 